\title{
HAK PEREMPUAN DALAM WARISAN DI BUDAYA NIAS WILAYAH DESA GOLAMBANUA II DITINJAU DARI KITAB BILANGAN 27:1-11
}

\author{
Warlina Hulu \\ warlinahulu@gmail.com \\ Sekolah Tinggi Teologi Jemaat Kristus Indonesia
}

\begin{abstract}
Nias culture has a speciality in the issue of heritage sharing for girls in Nias families. The rule has been passed down through generations as a traditional heritage or tradition that continues to be preserved. In fact, there are times when the distinction of inheritance has an impact on Nias women. This article therefore discusses how the Bible revisits the rules of inheritance division with the guidelines of the truth of the Word over culture.
\end{abstract}

Keywords: Nias, heritage sharing, girl, culture

\begin{abstract}
ABSTRAK
Budaya Nias memiliki kekhususan dalam masalah pembagian warisan bagi anak perempuan dalam keluarga Nias. Aturan itu sudah diturunkan secara turun temurun sebagai sebuah warisan adat atau tradisi yang terus dilestarikan. Pada kenyataannya ada kalanya pembedaan hak waris tersebut menimbulkan dampak bagi para perempuan Nias. Oleh sebab itu, artikel ini membahas tentang bagaimana Alkitab meninjau kembali aturan pembagian warisan dengan pedoman kebenaran Firman di atas budaya.
\end{abstract}

Kata Kunci: Nias, Hak perempuan, budaya

\section{PENDAHULUAN}

Budaya Nias di Desa Golambanua II Perempuan tidak berhak memperoleh warisan, karena perempuan dianggap bukan sebagai keturunan penerus marga dalam keluarga. Hal ini yang menjadi dasar bagi masyarakat Nias Desa Golambanua II untuk mempertahankan adat yang sudah ada, dimana orangtua tidak memberikan hak waris kepada anak perempuan.

Menurut peneliti, berdasarkan pengalaman sebagai orang Nias asli "Pembagian warisan dalam budaya Nias di Desa Golambanua II sering menimbulkan permasalahan." Ada tiga faktor yang sering menimbulkan permasalahan dalam pembagian warisan, yaitu:

Pertama, adalah hak anak laki-laki. Pembagian warisan antara anak pertama dengan anak kedua dan anak ketiga tidak sama bagiannya. Begitu juga dengan 
hak anak terakhir tidak sama dengan anak kedua dan anak ketiga. Sehingga hal ini sering diperdebatkan oleh anak kedua dan anak ketiga, karena mereka merasa diperlakukan tidak adil dalam hak warisan. Permasalahan pembagian warisan ini yang sering menimbulkan pertikaian diantara saudara, bahkan sampai terjadi saling membunuh antar saudara.

Kedua, berdasarkan wawancara yang dilakukan oleh peneliti dengan Bapak Sekhinaso sebagai Ketua Adat di Desa Golambanua II adalah "pembagian warisan, perempuan tidak mendapatkan bagian berdasarkan konsep yang dimiliki oleh masyarakat adalah anak laki-laki yang dapat mewarisi seluruh harta orang tua sebagai keturunan keluarga."' Sehingga orang yang tidak memiliki anak laki-laki dan hanya memiliki anak perempuan sering terjadi masalah yang besar, karena dalam budaya Nias jika tidak memiliki anak laki-laki maka yang berhak mewarisi warisan orang tuanya adalah anak laki-laki saudara ayahnya.

"Berdasarkan hukum adat yang berlaku, maka anak laki-laki saudara ayahnya memiliki hak untuk mewarisi warisan saudaranya. Dampak yang buruk sering terjadi perselisihan, permusuhan, bahkan pembunuhan antara satu dengan yang lain di dalam satu keluarga." Karena saudara yang terdekat dalam keluarga itu merasa memiliki hak dan anak perempuan keluarga yang menjadi keturunan tersebut tidak mendapatkan hak waris.

Anak perempuan melakukan pemberontakan kepada orangtua mereka karena tidak mendapat warisan, sedangkan anak perempuan selama bersama dengan orangtua bekerja keras untuk memenuhi kebutuhan keluarga, dan ketika sudah menikah orangtua memberikan tanggungjawab yang sama dengan anak laki-laki dalam pelunasan hutang keluarga. Orang tua yang tidak memiliki anak laki-laki menjadi tanggungjawab anak perempuan dalam mengurus ketika sudah tua.

Anak perempuan menuntut hak sebagai anak kepada orangtua sesuai tanggungjawab yang diberikan kepada mereka. Perempuan sering menggunakan argumen bahwa orangtua menuntut tanggungjawab anak-anak perempuan, namun tidak memberikan apa yang menjadi haknya. (khegu zisekhi kheu goboula) artinya bahwa sesuatu yang baik untuk kamu tetapi yang busuknya kamu berikan kepada saya. Karena apabila dalam keluarga tidak memiliki anak laki-laki dan anak perempuan menjadi ahli waris maka akan memicu per-masalahan dalam keluarga. Saudara laki-laki pewaris akan memberontak karena tidak sesuai dengan hukum adat yang berlaku atau yang biasa dilakukan oleh masyarakat Nias.

${ }^{1}$ lbid., Wawancara Sekhinaso. 
Ketiga orang tua di budaya Nias wilayah Desa Golambanua II selalu menginginkan kelahiran anak laki-laki walaupun anak perempuannya sudah banyak tetapi jika anak laki-lakinya belum ada maka mereka akan terus berharap memiliki anak karena bagi mereka hanya anak laki-lakilah yang akan menjadi keturunan atau penerus marga dalam keluarga tersebut. Budaya Nias wilayah Desa Golambanua II dikenal dengan banyak anak. Umur tualah yang membuat mereka berhenti mengharapkan laki-laki. Jadi yang membatasi mereka ingin memiliki anak itu adalah usia.

Kristen seharusnya memiliki standar hidup yaitu Alkitab. Alkitab orang percaya sebagai pedoman, peraturan-peraturan dan hukum dalam tata cara kehidupan. Namun dalam kenyataanya masalah pembagian warisan di Nias wilayah Desa Golambanua II ini berbeda sekali dengan pandangan Alkitab. Peneliti akan meneliti hukum pembagian warisan dalam kitab Bilangan 27:1-11. Salah satu hukumnya adalah anak perempuan memiliki hak waris apa bila di dalam keluarga tersebut tidak ada anak laki-laki.

Berdasarkan masalah-masalah di atas sehingga peneliti meneliti mengapa anak perempuan di budaya Nias wilayah Desa Golambanua II ini tidak diperkenankan untuk memiliki hak di dalam warisan keluarga. Peneliti berharap supaya dapat memberikan pemahaman terhadap anak perempuan bahwa mereka adalah sama-sama makhluk ciptaan Tuhan yang berharga sama dengan anak laki-laki, dan juga pemahaman yang baru terhadap orangtua, tentang bagaimana memperlakukan perempuan dan memberikan hak-hak yang yang sepantasnya dimiliki oleh anak perempuan ditinjau dari kebenaran Alkitab. Hal ini yang menjadi dasar bagi peneliti untuk memberikan pemahaman yang baru kepada masyarakat perlakuan yang benar kepada anak perempuan.

\section{METODE PENELITIAN}

Artikel ini disusun dengan menggunakan metode kualitiatif deskriptif dengan pendekatan historis di wilayah Nias berdasar fakta di lapangan yang diperoleh dari observasi lapangan. Kemudian untuk mengupas bagian Firman Tuhan yang menjadi alat peneliti untuk memberikan penilaian dalam pembahasan adalah didasarkan dari eksegesa Kitab Bilangan 27 :1-11.

\section{PEMBAHASAN DAN HASIL}

\section{Pengertian Hak Waris Secara Etimologi}

Hak menurut Kamus Besar Bahasa Indonesia adalah wewenang atau kekuasaan. Sedangkan warisan adalah harta yang dimiliki seseorang atau harta peninggalan yang ditinggalkan pewaris kepada ahli waris atau dari orang yang telah 
meninggal dunia. "Secara etimologi warisan berasal dari bahasa Arab Al-miirats dalam bahasa Arab ini adalah bentuk masdar (infinititif) dari kata waritsayaritsu-irtsan-miiraatsan."

Jadi hak waris adalah orang yang menerima wewenang harta pusaka dari orang yang telah meninggal sesuai hukum ataupun orang yang mewarisi. Maknanya adalah cara berpindahnya sesuatu dari seseorang kepada orang lain atau dari suatu kaum kepada kaum yang lain." Sedangkan dari pengertian hak waris diatas merupakan seseorang yang memiliki wewenang untuk memperoleh suatu warisan dari keluarga atau yang lain sesuai dengan hukum dan peraturan yang ada.

\section{Pengertian Hak Waris dalam Alkitab}

Pengertian hak waris dalam Perjanjian Lama dan Perjanjian Baru memiliki perbedaan. Perjanjian Lama membahas tentang warisan milik pusaka yang diberikan Allah kepada orang-orang Israel sebagai penggenapan janji yang dibuat antara Allah dan Abraham. Sedangkan dalam Perjanjian Baru lebih membahas tentang pengertian warisan secara rohani.

- Pengertian Hak Waris Menurut Kitab Perjanjian Lama

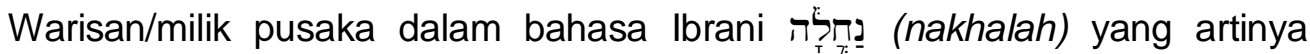

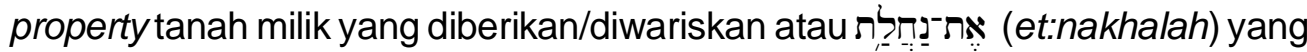
artinya possession adalah milik pusaka atau warisan. Kata ini terdapat terutama dalam Kitab Bilangan dan Kitab Ulangan yang mengacu pada tanah perjanjian yang ditetapkan bagi keluarga Israel. Karena tanah itu Allah berikan sebagai milik pusaka umat Israel, dan mereka tidak boleh melepaskan hak milik atas tanah mereka secara permanen. Jika mereka menjualnya maka tanah itu akan dikembalikan pada tahun Yobel (Im 25:23-38).

Alkitab memberikan peraturan khusus mengenai hak waris tanah keluarga: putra sulung mendapat bagian dua kali lipat (UI 21:15-17), jika tidak memiliki anak laki-laki maka anak perempuan dapat memiliki hak waris dari tanah ayahnya. (Bil. 27:8); jika tidak memiliki keturunan langsung maka tanah dapat diwariskan pada pelayan atau saudara jauh. Tujuan warisan tanah itu adalah supaya keluarga mereka mempunyai cara memperoleh nafkah dan kelangsungan hidup. Warisan selalu dianggap sebagai norma dan dalam kitab Amsal 13:22 warisan dianggap sebagai kebajikan.

Hak waris diberikan kepada perempuan apabila tidak memiliki anak laki-laki tetapi dengan syarat bahwa anak perempuan harus menikah dengan salah

2 Departemen Pendidikan Nasional, Kamus Besar Bahasa Indonesia Pusat Bahasa Edisi Keempat, (Jakarta: Gramedia Pustaka Utama, 2008),1556. 
satu kaum dari keluarganya. Sebab milik pusaka nenek moyangnya tidak boleh beralih kepada suku lain, itulah yang menjadi perintah dan peraturan yang diberikan Tuhan kepada bangsa Israel. Sehingga milik pusakanya tetap tinggal dalam suku mereka sendiri turun temurun.

Hak waris dalam Perjanjian Lama dapat disimpulkan bahwa hak yang diberikan kepada ahli waris sebagai hadiah kehormatan dan dukungan dalam meneruskan status dan nama baik keluarga. Hal ini yang terus menerus mereka lakukan oleh orang-orang Israel sebagai hukum yang harus dilakukan dalam kehidupannya untuk selalu menjaga silsilah keturunan dalam budaya Yahudi. Dengan adanya warisan, maka orang akan terus mengenal nama sejarah nenek moyang yang mewariskan segala sesuatu kepada keturunannya. Hal ini sangat penting untuk menjadi ahli waris supaya daftar nama keluarga tetap ada dan terus dipertahankan. Itulah sebabnya anak laki-laki lebih utama untuk menjadi ahli waris karena yang meneruskan keturunan keluarga sedangkan perempuan, dia dapat menjadi ahli waris apabila dalam keluarga tidak ada anak laki-laki, maka dia menjadi penerus keturunan dengan catatan dia tinggal di tengah-tengah saudara atau di dalam tanah warisan ayahnya. Bahkan ketika menikah dia harus menikah dengan sanak saudara atau kerabatnya supaya daftar keturunan ayahnya tetap ada.

\section{- Pengertian Hak Waris Menurut Kitab Perjanjian Baru}

Perjanjian Baru membahas tentang warisan secara rohani. Bahkan dalam Lukas 12:13-21, Yesus meremehkan orang-orang yang mementingkan warisan dunia, dengan menjelaskan bahwa hal itu seringkali melahirkan keserakahan dan obsesi dengan harta. Tuhan Yesus lebih menekankan pengajaran tentang warisan kerajaan sorga, bukan lagi tentang harta dunia atau secara fisik melainkan warisan secara spiritual. Sangat berbeda dengan perjanjian Lama yang sangat ditekankan mengenai hukum waris yang harus diperoleh oleh setiap orang.

Warisan orang-orang percaya seharusnya berasal dari Allah, seperti bangsa Israel yang menerima warisan dari Allah (Kis 20:32; Ef 1:11,14,18). Dan seperti Abraham (Ibr. 11:8,13), orang-orang percaya tidak menerima warisan sekarang di dunia ini (1 Pet 1:4). Apakah warisan yang dinantikan orang percaya? Mazmur 37:11 dan Matius 5:5 mengatakan bahwa kita diwariskan dunia secara keseluruhan. Yakobus 2:5 menyebut bahwa warisan kita adalah kerajaan Allah, dan Ibrani 11:16 menyebutnya sebagai negeri yang di surga. I Korintus 2:9 mengajar bahwa tempat itu begitu istimewa, sehingga "Apa yang tidak pernah dilihat atau didengar oleh manusia, dan tidak pernah pula timbul dalam pikiran manusia, itulah yang disediakan Allah untuk orang-orang yang mengasihi-Nya." 
Wahyu 21 menggambarkan langit dan bumi baru dimana Allah akan berdiam dengan umat-Nya dan menghapus segala air mata, dukacita, penderitaan, dan kematian.

Jadi warisan dalam Perjanjian Lama sangat penting bagi orang Israel karena pusaka yang di wariskan oleh nenek moyang mereka yang harus dipertahankan untuk tetap tinggal pada kaum suku keluarga masing-masing. Warisan ini berbentuk fisik, yang berbicara tentang harta dunia yang dimiliki oleh setiap manusia sementara, Sedangkan Perjanjian Baru adalah warisan Kerajaan Sorga/kehidupan kekekalan yang telah dijanjikan oleh Tuhan Yesus sendiri. Perjanjian Baru tidak lagi bicara soal warisan berbentuk fisik tetapi Tuhan Yesus selalu mengajarkan murid-murid-Nya untuk memikirkan tentang warisan sorgawi, bukan warisan duniawi.

2. Hukum Waris Menurut Hukum yang Berlaku di Indonesia

- Pengertian Hukum Waris

Hukum waris adalah "bagian dari hukum kekeluargaan yang sangat erat kaitannya dengan ruang lingkup kehidupan manusia sebab setiap manusia pasti akan mengalami hukum yang dinamakan kematian." Warisan adalah perkara yang sangat penting dalam kehidupan manusia. "Menurut Wirjono Prodjodikoro warisan adalah "soal apakah dan bagaimanakah pelbagai hak dan kewajiban tentang kekayaan seorang pada waktu ia meninggal dunia akan beralih kepada orang yang masih hidup, Tidak hanya untuk diri pribadi, melainkan juga untuk anak cucu kelak. ${ }^{3}$

Peneliti simpulkan bahwa hukum waris diartikan sebagai hukum yang mengatur tentang kedudukan harta kekayaan seseorang setelah pewaris meninggal dunia, dan cara-cara berpindahnya harta kekayaan itu kepada orang lain atau ahli waris.

- Macam-macam Hukum Waris di Indonesia

Indonesia adalah negara multikultural. Berbagai aturan yang ada pun tidak dapat membuat batas-batas kultur yang ada. Sama berlakunya untuk hukum waris. Hukum Waris yang berlaku di Indonesia adalah hukum waris adat, hukum waris Islam dan hukum waris perdata. Masing-masing hukum waris itu memiliki aturan yang berbeda-beda.

Hukum Waris Adat

Hukum waris adat adalah hukum yang meliputi norma-norma hukum yang menetapkan harta kekayaan baik yang material maupun yang inmaterial yang

\footnotetext{
${ }^{3}$ Maman Suparman, Hukum Waris Perdata, (Jakarta: Sinar Grafika,2017), 7
} 
manakah dari seseorang yang dapat diserahkan kepada keturunannya serta yang sekaligus juga mengatur cara dan proses peralihannya. Menurut Hilman Hadikusuma; "hukum waris adat adalah hukum adat yang memuat garis-garis ketentuan-ketentuan tentang sistem dan azas-azas hukum waris, tentang harta warisan pewaris dan ahli waris, serta cara bagaimana harta warisan itu dialihkan penguasaan dan kepemilikannya dari kepada ahli waris."

Hukum waris adat di dalamnya terdapat adanya kesatuan dan berjenis-jenis dalam hukum adat Indonesia dapat disusun aturan-aturan pokok dan azasazas yang sangat umum berlakunya, tetapi tidak dapat disusun suatu aturan yang di semua lingkungan hukum yang berkelakuan sama. Dalam hukum adat ini para ahli waris tidak dapat ditetapkan karena di berbagai daerah itu terdapat bermacam-macam sistem kekeluargaan. Jadi para ahli warisnya digolongkan berdasarkan sifat kekeluargaan masing-masing. Tetapi yang pasti jadi ahli waris adalah anak.

Setiap budaya memiliki adat yang berbeda dan juga memiliki hukum yang paling penting dan paling utama dalam menjadikan sebagai tatanacara hidup mereka. Sebab banyak budaya yang lebih mengutamakan hukum Adat untuk menjadi hukum paling utama sebagai tatanacara dalam kehidupan masyarakat setempat.

Contoh beberapa budaya yang mengutamakan hukum adat di dalam kehidupan masyarakat seperti "budaya Aceh; mereka sangat menjunjung tinggi Adat istiadat dalam masyarakatnya. Hal ini terlihat dengan masih berfungsinya institusi-institusi adat di tingkat "gampông" atau mukim. Meskipun Undangundang no 5 tahun 1975 berusaha menghilangkan fungsi mukim, keberadaan Imum mukim di Aceh masih tetap diakui dan berjalan. Hukum adat tetap masih memegang peranan dalam kehidupan masyarakat." 5

Kemudian budaya Nias, Budaya Nias juga sangat menjujung tinggi hukum adat dari pada hukum undang-undang yang berlaku. Hal ini dibuktikan bahwa setiap ada masalah dalam masyarakat maka hukum yang mereka pakai dalam menyelesaikan adalah hukum adat, bahkan dalam tatana cara hidup mereka lebih banyak mengikuti hukum adat daripada hukum negara. Sebab sebelum hukum negara masuk ke dalam suatu daerah tertentu, maka daerah itu sudah lebih dulu ada budaya dan hukum adat, yang masyarakat lakukan dalam tatana cara kehidupan masyarakatnya.

\footnotetext{
${ }^{4}$ https:// karya tulis ilmiah.com (selasa,20-11-2018)

${ }^{5}$ Lidahtinta.http// www.wordpress.com.Adat dan Hukum di Aceh, (Senin, 21/01/2019).
} 


\section{Hukum Waris Perdata}

Pengertian hukum waris perdata adalah sebuah aturan yang undang-undangnya merujuk pada kitab undang-undang hukum perdata (KUH Perdata). Dalam undang-undang tersebut hukum waris dijumpai pada pasal 830 sampai dengan pasal $1130 \mathrm{KUH}$ Perdata. Secara keseluruhan pengertian hukum waris perdata disimpulkan dari beberapa pendapat ahli hukum adalah sebuah hukum yang mengatur mengenai pemindahan hak kemilikan dari harta yang ditinggalkan oleh pewaris yang kemudian ia menentukan berapa jumlah yang harus dibagikan kepada ahli waris dan siapa saja yang berhak memiliki warisan tersebut.

Pembagian warisan dalam hukum KUH Perdata, tidak membedakan antara perempuan dan laki-laki. Mereka diberikan hak yang sama dalam warisan orang tua, sebagaimana dinyatakan dalam pasal 852, di mana bagian mereka sama besar, dan mewaris kepala demi kepala dan mengenal sistem pergantian. Hal ini dibuktikan bahwa hak laki-laki dan perempuan adalah sama. Karena mereka adalah keturunan yang sama.

Hukum KUH Perdata mengakui adanya kesamaan hak antara laki-laki dan perempuan. Artinya adalah perempuan mendapatkan hak yang sama dengan laki-laki, karena berasal dari keturunan yang sama.

- Unsur-unsur Terjadinya Pewarisan

Ada tiga syarat terjadinya pewarisan, yaitu: pertama ada orang yang meninggal dunia (pewaris) yang akan mewarisi harta warisannya kepada ahli warisnya. Kedua ada orang yang masih hidup sebagai ahli waris, yang akan memperoleh warisan pada saat pewaris meninggal dunia (ahli waris). Ketiga adalah ada sejumlah kekayaan yang ditinggalkan oleh pewaris (harta warisan). Ketiga hal ini ada sehingga terjadinya pewarisan kepada orang lain.

Pengertian pewaris menurut Eman Suparman adalah "seseorang yang meninggal dunia, baik laki-laki maupun perempuan yang meninggalkan sejumlah harta kekayaan baik berupa hak maupun kewajiban yang harus dilaksanakan selama hidupnya, baik dengan surat wasiat maupun tanpa surat wasiat."6 Sedangkan menurut Hazainuddin Ali pewaris adalah "seseorang yang meninggal dunia, baik laki-laki atau perempuan yang meninggalkan sejumlah harta kekayaan maupun hak-hak yang diperoleh, beserta kewajiban-kewajiban yang harus dilaksanakan selama hidupnya, baik dengan surat wasiat maupun tanpa surat wasiat. Namun dapat diartikan juga, orang yang masih hidup tetapi ingin memindahkan hak atas harta kekayaannya kepada orang lain."

\footnotetext{
${ }^{6} /$ bid., Maman Suparman,. 24

${ }^{7}$ Ibid., Maman Suparman., 16
} 


\section{- Pengertian Ahli Waris}

Ahli waris menurut Kamus Besar Bahasa Indonesia adalah "orang-orang yang berhak menerima warisan atau harta pusaka dari pewaris." Menurut Eman Suparman ahli waris adalah orang yang berhak menerima pusaka (peninggalan orang yang telah meninggal )." Jadi ahli waris adalah orang-orang yang berhak menerima pusaka atau harta peninggalan pewaris yang telah ditentukan baik secara hukum maupun oleh pewaris sendiri, yang meneruskan mewarisi harta dari pewaris.

\section{- Pengertian Harta Warisan}

Pengertian secara umum harta warisan adalah semua barang benda yang ditinggalkan oleh seseorang yang meninggal dunia (pewaris) baik barang benda yang sudah dibagi maupun yang belum dibagi atau memang tidak dibagi.

Pengertian pada umumnya bahwa harta warisan terbagi-bagi kepemilikannya kepada para warisnya, dan suatu kepemilikan atas harta warisan tidak berarti kepemilikan mutlak perseorangan tanpa fungsi sosial. Oleh karena itu, menurut hukum adat suatu pemilikan atas harta warisan masih dipengaruhi oleh sifat-sifat kerukunan dan kebersamaan, yang dipengaruhi oleh rasa persatuan keluarga dan rasa keutuhan tali persaudaraan yang merupakan hal yang sangat penting dalam pertimbangan pewarisan. ${ }^{8}$

Harta warisan menurut Kamus Besar Bahasa Indonesia adalah kekayaan berwujud dan tidak berwujud yang bernilai dan yang menurut hukum dimiliki. Menurut KUH Perdata, darimana pun asal harta tetap merupakan satu kesatuan yang secara keseluruhan beralih dari tangan orang yang meninggal kepada para ahli warisnya. Jadi harta warisan itu tidak dapat dikenal dengan nama harta bawaan melainkan semua setelah menjadi suami istri baik dari suami maupun harta yang dibawa oleh istri akan menjadi satu kesatuan dari dimiliki oleh bersama-sama dalam keluarga.

\section{- Dasar Hukum Tentang Warisan Menurut KUH Perdata}

Dasar hukum ahli waris dapat mewarisi sejumlah harta pewaris menurut sistem hukum waris melalui dua cara yaitu: Pertama, menurut ketentuan undangundang (ab intestato atau wettelijk erfrecht). Kedua, ditunjuk dalam surat wasiat (testamentair erfrecht)."

Menurut KUH Perdata, ahli waris menurut undang-undang atau ahli waris $a b$ intestato berdasarkan hubungan darah dibagi menjadi empat golongan yaitu:

\footnotetext{
${ }^{8}$ Hilman Hadikusuma, Hukum waris adat (Bandung:Citra aditya Bakti,1993), 35.
} 
Pertama: ahli waris dalam golongan pertama adalah keluarga dalam garis lurus kebawah, meliputi anak-anak beserta keturunannya, tanpa membedakan jenis kelamin, waktu kelahiran dari perkawinan pertama atau kedua, sebagaimana diatur dalam pasal 852, dimana bagian mereka sama besar, dan mewaris kepala demi kepala dan mengenal sistem pergantian.

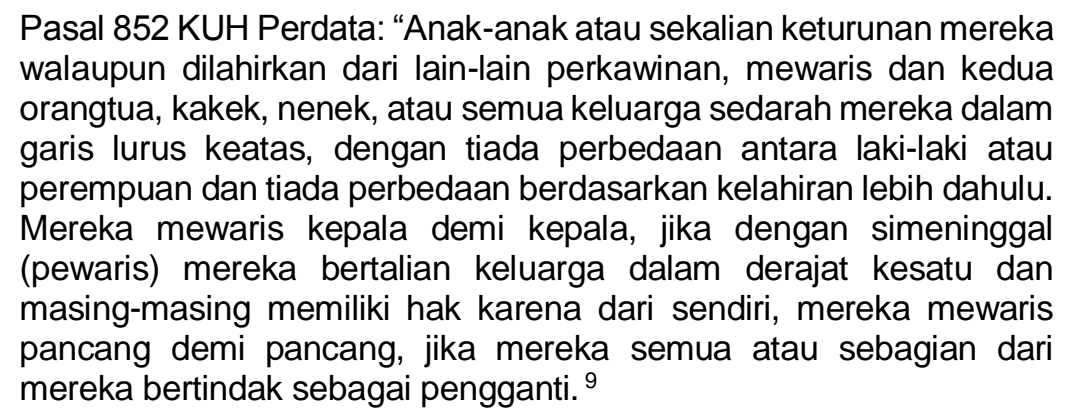

Kedua: Ahli waris golongan kedua, yaitu keluarga dalam garis lurus ke atas, meliputi orang tua, saudara-saudara laki-laki dan perempuan dan keturunannya, maka warisan jatuh kepada keluarga sedarah golongan kedua. Pembagian harta peninggalan ini diatur dalam pasal 854,857, dan $859 \mathrm{KUH}$ Perdata. Orang tua menerima bagian yang sama dengan bagian saudara laki-laki atau perempuan tetapi tidak kurang dari seperempat (pasal 854 ayat (2) KUH Perdata).

Ketiga: Ahli waris golongan ketiga yaitu, keluarga sedarah dalam garis lurus keatas jika pewaris tidak meninggalkan keturunan maupun suami atau istri, orang tua, saudara-saudara atau keturunan saudara-saudara, maka yang mendapat giliran adalah keluarga sedarah selanjutnya di dalam garis lurus ke atas yang disebut golongan ke III. Menurut pasal 850 dan pasal 853 ayat (1) KUH Perdata, harta peninggalan harus dibagi atau dibelah menjadi dua bagian yang sama besarnya, satu bagian untuk semua keluarga sedarah dalam garis sibapak lurus ke atas satu bagian lainnya untuk semua keluarga sedarah yang sama dalam garis ibu.

Keempat: Ahli waris golongan keempat yaitu keluarga lainnya dalam garis menyamping yang dibatasi sampai dengan derajat keenam, baik dari pihak ayah maupun dari pihak ibu. Pasal 858 KUH Perdata, menentukan : "dalam hal tidak adanya saudara-saudara laki-laki dan perempuan dan tidak adanya pula keluarga sedarah dalam satu garis ke atas, setengah bagian dari warisan menjadi bagian sekalian keluarga dalam garis ke atas yang masih hidup, sedangkan setengah bagian lainnya, kecuali dalam hal tersebut dalam pasal 859 menjadi bagian para sanak saudara dalam garis yang lain. ${ }^{10}$

\footnotetext{
${ }^{9}$ Benyamin Asri dan Thabrani Asri, Dasar-dasar Hukum Waris Barat (suatu pembahasan Teoritis dan Praktek), (Bandung: Tarsito, 1988), 5.

${ }^{10} \mathrm{lbid}$., Hilman Hadikusuma. 34-36
} 
Jadi, ahli waris yang utama adalah anak-anak yang merupakan keturunan dari pewaris baik laki-laki maupun perempuan yang memiliki hak utama, kemudian ketika ahli waris utama tidak ada maka ahli waris golongan kedua yang memiliki hak yaitu saudara pewaris baik laki-laki maupun perempuan dan begitupun seterusnya sampai pada golongan keempat sekiranya tidak ada golongan pertama sampai ketiga.

Dapat disimpulkan bahwa menurut hukum KUH perdata ahli waris merupakan anak-anak kandung pewaris tanpa ada perbedaan antara laki-laki dan perempuan. anak laki-laki dan anak perempuan memiliki hak yang sama dalam mewarisi harta orang tua.

\section{Warisan Keluarga Nias}

\section{a. Pengertian Hak Waris Dalam Bahasa Nias}

Hak waris dalam bahasa Nias adalah kuaso harato nirei zatua sino latatuke he amakhoita bahe gei oroisa ma zatua melenasa larei gulidane. (artinya kuasa atau wewenang yang dimiliki untuk menjadi ahli waris atau yang dapat memiliki warisan baik secara hukum maupun sesuai pesan orang tua sebelum meninggal. Karena orang yang memiliki hak waris adalah orang yang sudah ditentukan oleh hukum adat (fondrake) dan juga orang tua. Walaupun ketetapan hukum (fondrake) itu tidak tertulis namun masyarakat Nias sangat taat pada hukum tersebut karena mereka meyakini bahwa ketika ada orang yang melanggar hukum atau fondarake maka orang itu akan terkena kutuk.

Arti dari fondrake itu merupakan kumpulan dan sumber dari segala hukum yang menjadi landasan hidup ono niha (orang nias) baik perorangan maupun masyarakat banyak. Pada dasarnya fondrake menekankan pada sikap agar berbuat baik dan melarang segala macam corak kejahatan serta memberi dorongan dan petunjuk untuk berbuat menurut jiwa dari fondrake tersebut. ${ }^{11}$

Jiwa fondrake tersebut adalah dikenal menurut istilah aslinya, yang mengatakan masi-masi (kasih sayang), meli-meli (pengasuhan/pencegahan, rourou (pendo-rong berbuat/pengasahan. Fondrake ini dibuat untuk menolong masyarakat supaya mereka memiliki tatacara kehidupan yang lebih baik. Fondrake pada dasarnya sumpah yang diikrarkan-nya pada pembentukan ori (kumpulan desa) ketika para kepala desa berkumpul untuk menentukan nilai-nilai yang harus dilakukan. Fondrake menegaskan kutuk terhadap siapa pun yang melanggar ketetapan.

Fondrake pertama "diadakan oleh Hia yang terkenal dari Gomo, dan setiap kali ada anggota desa baru, diadakan fondrake untuk menegaskan ulang aturan

\footnotetext{
${ }^{11}$ Novelaoli. Blogspot.com/2008. (Jumat, 19-10-2018), pukul 09.15 wib.
} 
tersebut, dan selalu ada babi yang dikorbankan. Pelanggaran terhadap aturan leluhur diyakini mendapat hukuman berupa sakit dan malapetaka."12

Fondrake ini menolong masyarakat Nias untuk meningkatkan rasa kasih sayang terhadap anak-anak perempuan. dengan adanya Fondrake ini perempuan dapat merasakan kasih sayang orang tua, seperti orang tua mengijinkan untuk perempuan bersekolah sekalipun harus dibawah laki-laki, dan juga dapat diberikan barang-barang mewah, seperti emas, uang, pakaian dan lain sebagainya. ${ }^{13}$

Pada zaman dahulu perempuan tidak mendapatkan kasih sayang seperti mengijinkan ke sekolah, barang-barang mewah dan lain sebagainya melainkan hanya diberi makan, tetapi dengan adanya hukum Fondrake ini membuat perubahan yang dapat menolong perempuan. Walaupun ada beberapa orang tua yang mengabaikan hukum ini dan menganut ajaran yang pada mulanya orang Nias. Tetapi sudah banyak yang melakukan hukum Fondrake ini yang dijadikan sebagai tatana cara hidup masyarakat.

b. Pembagian Warisan

Pembagian warisan kepada anak laki-laki diberikan sesuai kedudukan masingmasing. Orangtua harus memperhatikan cara pembagian warisan kepada anak-anaknya laki-laki supaya tidak menjadi batu sandungan kepada anakanaknya karena merasa tidak mendapatkan keadilan dalam pembagian warisan orang tuanya. Sebab itu mereka menggunakan hukum adat sebagai landasan dalam pembagian warisan.

- Posisi Laki-laki dalam Hak Waris

Posisi laki-laki memiliki posisi yang berbeda-beda, antara anak yang satu dengan anak yang lain. Posisi anak laki-laki sulung berbeda dengan posisi anak laki-laki kedua, ketiga dan seterusnya, begitu juga dengan anak laki-laki bungsu. Dalam hal ini yang sering menjadi masalah dalam keluarga, anak-anak terjadi konflik antara satu sama lain, bahkan kepada orang tua. Bahkan sampai terjadi membunuh saudaranya sendiri karena merasa tidak mendapatkan keadilan dalam memiliki hak waris dari orang tua. Kejadian ini di budaya Nias bukan lagi suatu hal yang baru, tetapi sudah sering terjadi. Keadaan seperti ini membuat keadaan keluarga pada masyarakat Nias sangat memprihatinkan.

a) Posisi yang di dapat oleh Anak Sulung

Posisi yang di dapat anak sulung dalam hak waris memiliki keistimewaan dibandingkan dengan anak-anak lainnya. Sebab anak sulung mendapatkan dua kali lipat dari harta ayahnya.

Praktek hak anak sulung di Israel kuno dimana hak-hak tertentu diberikan kepada anak laki-laki sulung. Anak sulung laki-laki (anak

\footnotetext{
${ }^{12}$ S.Jebua 'Menyelusuri Sejarah Kebudayaan Ono Niha' 1984,hlm 447.

${ }^{13}$ Saranudin Halawa Wawancara melalui Telepon, (Selasa, 20 November 2018), 19.30 WIB
} 
laki-laki tertua dari sang ayah) menikmati status yang istimewa. la mewarisi porsi dua kali lipat dari harta ayahnya, menerima berkat khusus dari ayahnya, dan menggantikan ayahnya sebagai kepala keluarga, memegang otoritas atas anggota keluarga lainnya. ${ }^{14}$

Anak laki-laki sulung Adat Nias memiliki kesamaan dengan hak anak laki-laki sulung Israel. Adat Nias melakukan seperti yang dilakukan oleh orang Israel, memiliki posisi hak waris yang berbeda dengan anak kedua dan seterusnya. Anak sulung mendapatkan separuh dari harta orang tua yang menjadi hak miliknya. Hal ini sering memicu perselisihan, kesalahpahaman dan mereka saling membenci bahkan saling membunuh antara anak-anak yang lain. Alasan orangtua bahwa anak sulung mendapatkan hak yang lebih dari anak-anak yang lain, karena anak laki-laki sulung akan menggantikan posisi seorang ayah di dalam keluarga ketika ayahnya sudah tiada. Anak sulung, bertanggung jawab atas seluruh keluarganya, untuk mencukupkan nafkah maupun untuk segala sesuatu yang harus diputuskan di dalam keluarga.

Tanggung jawab anak laki-laki sulung sangat besar, karena semua yang terjadi di dalam keluarga harus dipertanggungjawabkan oleh anak laki-laki sulung. Tanggungjawab seorang ayah harus dipikul oleh anak laki-laki sulung d dalam keluarga. Tidak dapat dihindari, bahwa dia harus menerima tanggungjawab secara otomatis. Walaupun dalam prakteknya, terjadi kekacauan dalam keluarga karena kepemimpinan yang tidak baik terhadap keluarganya.

- Posisi yang Diperoleh Anak Laki-laki Bungsu

Kedudukan anak laki-laki bungsu memiliki hak yang istimewa di bawah anak sulung. Anak laki-laki bungsu memperoleh warisan sepertiga dari harta orang tuanya, karena anak bungsu mempunyai kewajiban untuk mengurus orangtuanya ketika sudah tidak dapat bekerja. Oleh karena itu, rumah orangtua tinggal di rumah anak laki-laki bungsu. Namun, tidak menutup kemungkinan juga dapat tinggal di rumah anak laki-laki sulung dan anak lakilaki lainnya, hanya pada umumnya orangtua biasanya tinggal bersama dengan anak laki-laki bungsu karena merupakan anak terakhir dan anak laki-laki bungsulah yang mewarisi rumah orangtua.

b) Posisi Perempuan dalam Hak Waris

Suku Nias/masyarakat adat Nias mengikuti hitungan hubungan kekerabatan melalui laki-laki, dimana dalam hal ini laki-laki maupun perempuan mengikuti garis keturunan ayah atau berlaku sistem keturunan dari pihak bapak

\footnotetext{
${ }^{14}$ Philip J. King dan Lawrence E. Stager, Kehidupan Orang Israel Alkitabiah, (Jakarta: Gunung Mulia, 2001), 53.
} 
(patrilineal) yaitu didasarkan atas pertalian darah menurut garis bapak. Sehingga hanyalah anak laki-laki yang menjadi ahli waris karena anak perempuan dianggap telah keluar dari kerabat bapaknya, jika ia telah menikah. ${ }^{15}$ Posisi perempuan dalam harta warisan orang tua tidak diperhitungkan. Artinya bahwa perempuan tidak diberikan posisi apapun dalam warisan orang tua, sebab dianggap telah keluar dari kerabat keluarga atau tidak menjadi generasi penerus keturunan nama dan marga keluarga. Perempuan ketika sudah dewasa akan menjadi milik orang lain, sehingga perempuan tidak terhitung sebagai generasi penerus keturunan keluarga.

c) Posisi Perempuan dalam Hukum Fondrake

Hukum Adat Nias pada zaman dahulu kala, Masyarakat Nias sangat kuat dalam hukum Adat. Seperti dalam kedudukan perempuan dalam warisan tidak diperhitungkan sama sekali, bahkan tidak mendapatkan harta warisan apapun kecuali dia dirawat dan dibesarkan oleh orangtua. Dalam perkembangannya para tokoh masyarakat menerapkan hukum Fondrake, yang mereka buat dan sepakati untuk dipercaya sebagai sumpah bagi mereka, bahwa masyarakat Nias berpedoman dengan hukum Fondrake.

Orangtua memberikan masi-masi (bentuk kasih orangtua) seperti dapat disekolahkan, dan dalam bentuk benda berharga, seperti emas, uang, pakaian. Hal ini yang dapat diterima oleh anak perempuan dalam harta orangtua.Inilah perubahan Hukum Adat yang dialami oleh masyarakat Nias. Orangtua pada zaman dahulu kala tidak mau menyekolahkan anak perempuan tetapi dengan adanya hukum Fondrake perubahan itu dilakukan. ${ }^{16}$

Posisi perempuan setelah adanya hukum Fondrake menjadi semakin ditinggikan nilainya, sekalipun belum sepenuhnya diubah. Hukum Fondrake ini perempuan mendapatkan kasih sayang orang tua selain dibesarkan, perempuan mulai diijinkan untuk sekolah sekalipun tidak melebihi laki-laki.

d) Alasan Perempuan Mendapatkan Perubahan Dalam Pemberian Kasih Sayang Orang Tua

Alasan anak perempuan mendapatkan kasih sayang yang melebihi sebelum adanya hukum Fondrake sehingga masyarakat lebih mengikuti hukum Fondrake daripada hukum yang pada mulanya. Sejalan dengan perkembangan zaman disertai kemajuan ekonomi, teknologi, pendidikan, dan sosial budaya terjadi pergeseran hukum dari Adat Nias awal zaman nenek moyang ke hukum yang berlaku saat ini. Terbukanya wawasan masyarakat Nias terhadap kemajuan dan perkembangan teknologi, yang pada akhirnya

\footnotetext{
${ }^{15}$ Soerjono Soekanto, Hukum Adat Indonesia, Jakarta, Rja Grafindo Persada, 2001, hlm 240

${ }^{16}$ Metiaro Tafönaö, Wawancara Melalui Telepon, (Rabu, 16 Januari 2019), 20.00 WIB
} 
mengikuti hukum Fondrake yang dipandang sesuai dengan perkembangan zaman. ${ }^{17}$ Sedangkan di kalangan masyarakat Nias yang tinggal di pedalaman serta masyarakat yang masih menganut dan mencintai hukum adat zaman dahulu, masih menggunakan hukum adat dari nenek moyang.

Perempuan biasanya mendapatkan bagian dalam bentuk barang-barang seperti emas, uang, motor, dan lain sebagainya. Perempuan diberikan bagian sesuai dengan kerelaan kasih sayang orang tua.

c. Dampak Tidak Mendapat Hak Waris

Berdasarkan Budaya Adat yang berlaku, perempuan tidak mendapatkan hak waris dalam keluarga. Perempuan tidak diperhitungkan dalam generasi penerus keluarga, sehingga tidak mendapatkan hak waris orang tua, melainkan hanya dianggap sebagai pelengkap dalam keluarga. Sebab perempuan ketika sudah dewasa menjadi istri orang dan pergi meninggalkan orang tua atau keluarganya. Ada beberapa dampak yang terjadi:

- Dampak Bagi Keluarga

Keluarga sangat merasakan dampak dari kondisi dimana orangtua yang masih berpedoman kepada adat dari nenek moyang mengenai pembagian warisan, dirasakan tidak adil oleh pihak perempuan, karena perempuan tidak punya hak waris. Mestinya pembagian warisan antara anak perempuan dengan anak laki-laki dilakukan secara adil, sesuai dengan perkembangan jaman. Sering terjadi perselisihan dalam keluarga ketika orangtua tidak dapat mengatasi dan menyelesaikan, serta memberikan pemahaman yang baik kepada anak-anaknya baik anak perempuan maupun anak lakilakinya. Anak laki-laki cenderung merasa berkuasa dan menekan perempuan, sehingga anak perempuan memberontak kepada orangtua dan timbul kesalahpahaman, sehingga dalam keluarga menjadi tidak harmonis dan tidak bahagia.

Adat Nias di Wilayah Desa Golambanua II, banyak keluarga yang mengalami kekacauan, dimana anak-anak perempuan mendapatkan perlakuan yang tidak adil dari orangtua. Anak-anak laki-laki merasa sangat berkuasa karena mereka adalah penerus keturunan dari keluarga, orangtua pun mendukung karena sudah menjadi tradisi adat yang berlaku.

\footnotetext{
${ }^{17}$ Mahadi, laporan hasil Penelitian Fakultas Hukum USU tentang Garis-garis Besar Hukum kekeluargaan dan Warisan di kalangan Suku Batak dan Nias, Lembaga Penelitian USU, Medan, 1972, HIm 47.
} 
Anak perempuan yang mengikuti perkembangan zaman menuntut hak waris kepada orangtua, karena anak perempuan lebih bekerja keras daripada anak laki-laki. Namun, anak perempuan tidak mendapatkan bagian warisan, sedangkan anak laki-laki mempunyai hak atas seluruh harta orangtua. Ketika anak perempuan menikah, orangtua dan saudara laki-laki meminta mahar dengan jumlah yang tidak sedikit sebagai ganti biaya pengasuhan anak perempuan. Hal ini dirasakan sangat tidak adil oleh perempuan, jika dibandingkan dengan pengorbanan yang telah dilakukan, ketika anak perempuan sudah mulai mampu untuk bekerja, diajak oleh orangtua untuk bekerja keras untuk menunjang kebutuhan keluarga.

Masyarakat sebagian yang sudah mengalami perubahan dalam mengikuti adat, namun bukan berarti mereka tidak mengikuti adat yang sudah lama mereka lakukan dengan turun temurun, karena hanya sebagian kecil yang telah mereka melakukan perubahan seperti dalam peningkatan pemberian kasih terhadap anak-anak perempuan. Anak perempuan diberikan kasih oleh orang tua melebihi sebelum mengikuti perkembangan dan dengan adanya hukum Fondrake yang disebut sebagai masi-masi (kasih sayang). Walaupun apa yang mereka berikan akan kembali kepada kepada orang tua sesuai dengan masi-masi yang telah diberikan terhadap anak perempuan dengan cara meminta mahar yang tinggi dalam pernikahan.

- Dampak Bagi Orang tua

Berdasarkan konsep yang dimiliki oleh orangtua, bahwa hanyalah anak laki-laki yang akan menjadi penerus keturunan keluarga sehingga harta yang mereka miliki pun diwariskan semuanya kepada anak-anak laki-laki. Sedangkan anak perempuan hanyalah sebagai pelengkap sehingga anak perempuan merasa tidak mendapat perlakuan yang adil, sehingga tidak jarang anak perempuan yang sudah mengalami perkembangan zaman dapat memberontak kepada orangtuanya. Orangtua memiliki dampak buruk bahwa anak perempuan sering memberontak terhadap orang tua.

Orang tua mengalami dampak bahwa sering kehilangan anak perempuannya dengan menghilangkan jejak dan merelakan anak perempuannya menikah dengan orang yang tinggal sangat jauh supaya dapat mengobati luka yang dipendam selama hidup bersama dengan orang tua. Sakit hati merasa diperlakukan tidak adil dalam keluarga, membuat perempuan mudah mengambil keputusan dalam memilih kehidupannya dengan orang lain. ${ }^{18}$

\footnotetext{
${ }^{18}$ Nur Iman Telaumbanua, Wawancara melalui Telepon (Hari Jumat, 22 Februari 2019), 19.00 WIB.
} 
Orangtua sulit untuk mengatasi persoalan seperti ini, karena mereka mengikuti adat sedangkan mereka juga membutuhkan anak perempuan yang membantu bagi mereka dalam memenuhi kebutuhan keluarga. Hal ini mengakibatkan kekacauan dan kesulitan dalam mengatasi persoalan antara mengikuti adat atau memihak kepada anak-anak perempuan dan memberikan perlakuan yang adil.

- Dampak Bagi Anak Perempuan

Dampak anak perempuan tidak memiliki hak dalam warisan orangtua menyebabkan anak perempuan memiliki konsep negatif dalam pikirannya.

Paradigma yang dimiliki anak perempuan terhadap dirinya bahwa perempuan hanyalah manusia yang diciptakan untuk melengkapi laki-laki yang kedudukannya disetarakan dengan barang-barang mewah yang dimiliki oleh orang tua. Dampaknya bahwa anak perempuan kehilangan jati diri sebagai manusia yang diciptakan sama berharganya dengan laki-laki. Sehingga anak perempuan kebanyakan putus asa dalam menghadapi tantangan hidup, banyak yang bunuh diri karena tidak memiliki harapan untuk masa depan yang dapat membawa kebahagiaan. Bahkan jarang anak perempuan memiliki impian yang tinggi karena dibatasi dengan paradigma yang dimiliki dari kecil sampai dewasa dalam keluarga yang tidak memberikan kesempatan dan dukungan untuk meraih impiannya. ${ }^{19}$

Paradigma yang di tanamkan dari kecil dalam keluarga bahwa perempuan tidak dapat bermimpi lebih jauh kedepan bahkan anak perempuan dilarang untuk memiliki cita-cita yang lebih tinggi sehingga membuat anak perempuan mayoritas berpikiran pendek, dan tidak memiliki rasa juang untuk impian yang di cita-citakan. Sebab pada dasarnya mereka dilarang untuk memiliki cita-cita yang tinggi, terlebih lagi memberi dukungan dan dorongan dalam mewujudkan mimpinya.

\section{Eksegesa Kitab Bilangan 27:1-11}

Kitab Bilangan merupakan "Kitab yang menyampaikan Hukum yang mengatur bangsa Israel dalam perjalanan menuju ke tanah perjanjian. Hukuman yang berulang-ulang menimpa umat itu karena ketidak taatan mereka dalam hukum yang telah Allah tentukan bagi mereka, sehingga banyak orang Israel yang tidak sampai pada tanah perjanjian itu karena mereka mati dan padang gurun menjadi tempat penguburan mereka." 20

\footnotetext{
${ }^{19}$ Marliana Gea, Wawancara (Minggu, 25 November 2018). 14.00 WIB

${ }^{20}$ Gary Edward Schnittjer, The Torah Stori (Malang: Gandum Mas, 2015), 462.
} 
1. Hak Waris Perempuan (ayat 1-8)

Hak waris perempuan dalam Kitab Bilangan 27:1-11, tentang anak-anak

Zelafehad menuntut hak warisnya karena ayahnya tidak memiliki anak lakilaki dan supaya hak waris dari ayahnya dipindahkan kepada mereka anakanak perempuan sebagai ahli waris dalam keturunan keluarganya dan nama ayahnya tidak dihapus dari kaum keluarganya.

- Permintaan Anak-anak Perempuan Zelafehad

"Mengapa nama ayah kami harus hapus dari tengah-tengah kaumnya, oleh karena ia tidak mempunyai anak laki-laki? Berilah kami tanah milik di antara saudara-saudara kami."

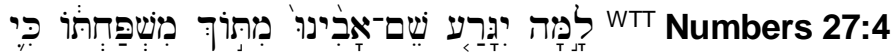

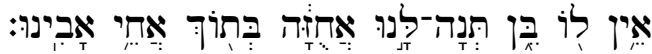

KJV Numbers 27:4 Why should the name of our father be done away from among his family, because he hath no son? Give unto us therefore a possession among the brethren of our father.

TB Numbers 27:4 Mengapa nama ayah kami harus hapus dari tengahtengah kaumnya, oleh karena ia tidak mempunyai anak laki-laki? Berilah kami tanah milik di antara saudara-saudara ayah kami."

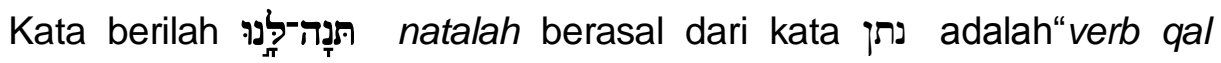
imperative masculine singular paragogic hehl. particle preposition suffix 1st person common plural." Dari kata berilah diartikan dari bahasa Ibrani memiliki beberapa arti yang pertama, Give artinya memberikan, mengorbankan, yang kedua present artinya pemberian sebagai hadiah, ketiga offer artinya menawarkan, memajukan. Keempat give in marriage pemberian dalam pernikahan.

Tafsiran Alkitab Masa Kini kata berilah diartikan dalam bahasa Inggris displace yang artinya memindahkan, menggantikan. Kata berilah dari beberapa arti dapat disimpulkan bahwa, anak Zelafehad meminta untuk memindahkan hak waris ayahnya kepada mereka anak-anak perempuan sebab ayahnya tidak memiliki anak laki-laki. Hal ini tidak menunjukkan mereka meminta hadiah yang hanya sekedar diminta oleh mereka, tetapi permintaan yang mereka sampaikan merupakan suatu kata perintah untuk dilakukan keharusan untuk dimiliki.

Budaya Nias khususnya wilayah desa Golambanua II, melakukan arti yang ke empat di atas adalah give in marriage artinya orangtua memberikan warisan sebagai hadiah pernikahan anak perempuannya. Dalam Alkitab 
arti kata berilah diartikan sebagai pemindahan hak kepada anak-anak perempuan. Arti ini yang lebih mendekati arti teks asli dalam Alkitab dari beberapa tafsir dan kata asli. Sehingga seharusnya hak waris perempuan bukan suatu hadiah tetapi hak yang seharusnya diperoleh oleh anak perempuan yang mutlak, dan tidak dikaitkan dengan masalah pernikahan harus membayar mahar yang tinggi ketika orangtua memberi warisan banyak kepada anak-anaknya.

- Arti Hak Waris

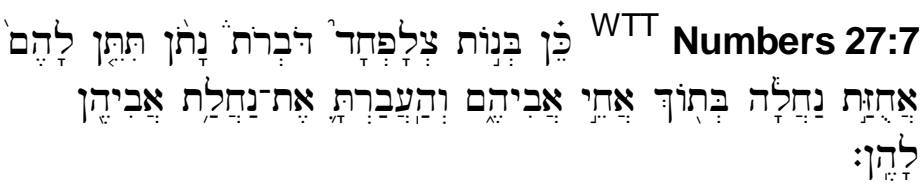

KJV Numbers 27:7 The daughters of Zelophehad speak right: thou shalt surely give them a possession of an inheritance among their father's brethren; and thou shalt cause the inheritance of their father to pass unto them.

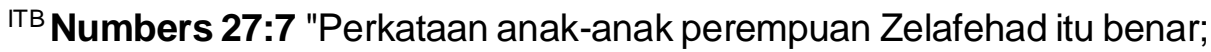
memang engkau harus memberikan tanah milik pusaka kepadanya di tengah-tengah saudara-saudara ayahnya; engkau harus memindahkan kepadanya hak atas milik pusaka ayahnya.

Hak waris dalam bahasa Ibrani memakai kata נַחָלזָה (nakhalah) yang

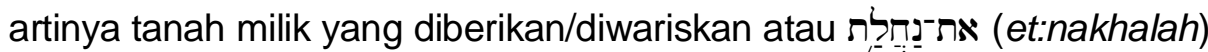
noun common feminine singular absoluteyang artinya possession adalah milik kepunyaan atau harta benda." 21

Dalam Perjanjian Baru Warisan menerjemahkan kata "Yunani kle, ronomos (kleronomos) yang berasal dari kata klhronomi, an (kleronomian) noun accusative feminine singular common from klhronomi, a yang artinya "bagian". Kata ini pada umumnya dipakai dalam ihwal menerima sesuatu menjadi hak, justru diterjemahkan menjadi "berhak menerima" (Gal 3:29; lbr $1: 2)^{\text {"22 }}$

Berdasarkan pengertian dalam Kitab Perjanjian Lama dan Kitab Perjanjian Baru bahwa hak waris merupakan bagian milik pusaka yang diterima oleh seseorang yang diberikan oleh pewaris menjadi Hak milik ahli waris.

\footnotetext{
${ }^{21}$ Bible Work, 10 Februari, 2019

${ }^{22}$ D.F. Walker, Konkordansi Alkitab (Jakarta: Gunung Mulia, 1994), 523.
} 
Pada waktu orang Israel telah 38 tahun telah lewat, selama waktu tersebut setiap orang laki-laki dan perempuan Israel yang berusia 20 tahun ke atas kecuali Kaleb, Yosua, dan Musa telah meninggal dunia karena ketidaktaatan mereka pada hukum Allah. Sehingga Zelafehad pun meninggal. Oleh sebab itu dalam (27:3) dikatakan "mati karena dosanya" berarti bahwa dia mati secara wajar. Kematiannya termasuk dalam hukuman atas seluruh bangsa itu karena telah memercayai pengintai-pengintai yang tidak beriman. ${ }^{23}$

Sampai dengan titik ini, hukum orang Ibrani memberikan hak waris hanya kepada anak laki-laki. Anak-anak perempuan Zelafehad, yang tidak mempunyai saudara laki-laki, datang kepada Musa untuk meminta harta pusaka ayah menjadi hak waris mereka. Allah memberitahu Musa bahwa bila seorang laki-laki meninggal tanpa memiliki anak laki-laki, warisannya akan turun kepada anak-anak perempuannya. (27:8).

Peneliti menarik kesimpulan bahwa apabila dalam keluarga tidak memiliki anak laki-laki maka hak waris akan dipindahkan kepada anak perempuan untuk memiliki hak dalam bagian milik pusaka orang tua. Sebab harta pusaka milik orang Israel tidak boleh beralih dari suku ke suku, tetapi orang Israel haruslah masing-masing memegang milik pusaka nenek moyangnya. (Bil 36:7-9). Supaya kaum keturunan keluarganya masih terus disebutkan dan tidak dihapus dari garis keturunan Israel.

2. Arti Penting Warisan Harus Dibagi (Ayat 9-11)

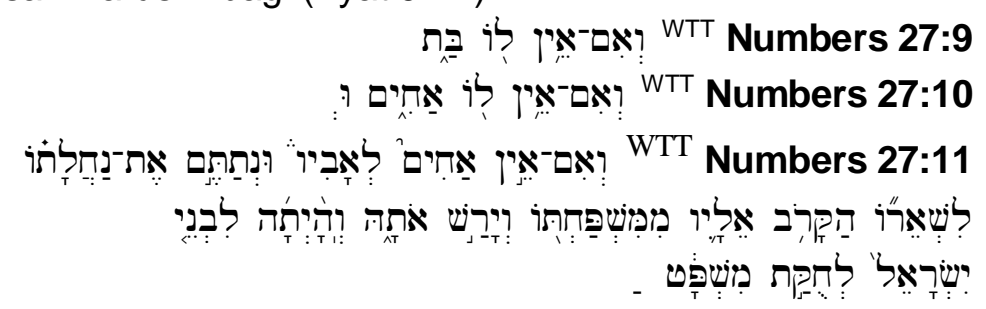

KJV Numbers 27:9 And if he have no daughter, then ye shall give his inheritance unto his brethren.

ITB Numbers 27:9 Apabila ia tidak mempunyai anak perempuan, maka haruslah kamu memberikan milik pusakanya itu kepada saudara-saudaranya yang laki-laki.

KJV Numbers 27:10 And if he have no brethren, then ye shall give his inheritance unto his father's brethren.

${ }^{23}$ Ibid., Lasor 124 


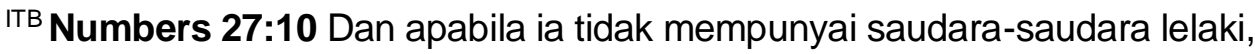
maka haruslah kamu memberikan milik pusakanya itu kepada saudarasaudara lelaki ayahnya.

${ }^{K J V}$ Numbers 27:11 And if his father have no brethren, then ye shall give his inheritance unto his kinsman that is next to him of his family, and he shall possess it: and it shall be unto the children of Israel a statute of judgment, as the Lord commanded Moses.

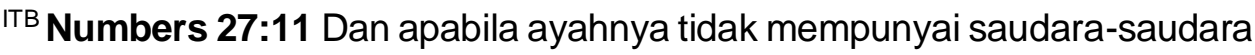
lelaki, maka haruslah kamu memberikan milik pusakanya itu kepada kerabatnya yang terdekat dari antara kaumnya, supaya dimilikinya." Itulah yang harus menjadi ketetapan hukum bagi orang Israel, seperti yang diperintahkan Tuhan kepada Musa.

Bilangan 27: 9-11, menyatakan, "Apabila ia tidak mempunyai anak perempuan, maka haruslah kau memberikan milik pusakanya itu kepada saudarasaudaranya yang laki-laki. Apabila ia tidak mempunyai saudara-saudara lelaki, maka haruslah kamu memberikan milik pusakanya itu kepada saudarasaudara lelaki ayahnya. Apabila ayahnya tidak mempunyai saudara-saudara lelaki, maka haruslah kamu memberikan milik pusakanya itu kepada kerabatnya yang terdekat dari antara kaumnya, supaya dimilikinya."

Ayat di atas sangat ditekankan tentang pembagian atau pemindahan hak waris apabila seseorang telah meninggal. Satu kalimat yang terus diulangulang yaitu "maka haruslah kamu berikan milik pusakanya kepada...ini menunjukkan bahwa pentingnya warisan harus dibagi atau dipindahkan hak kepada ahli waris.

"Milik pusaka (Ibrani nakhal, nakhala), kata ini terutama dalam Bilangan dan Ulangan, yang mengacu pada tanah perjanjian yang ditetapkan bagi tiap keluarga Israel. Tanah dalam bahasa Ibrani אֶרץ ('erets) artinya "Bumi,

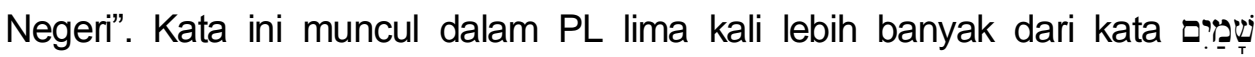
(samayim) artinya "Langit," "Surga". Tuhan berjanji memberikan tanah untuk Abraham dan keturunanya, Kejadian 15:18."24

"Janji berlaku sampai keturunanya (Kej 17:8). Terlibatnya keturunan dari Abraham, Ishak dan Yakub sebagai pewaris tanah itu tidak digenapi dalam waktu dekat semasa mereka masih hidup dan tidak terjadi dalam satu generasi, tetapi kegenerasi berikutnya."

${ }^{24}$ Karman Yonky, Bunga Rampai Teologi Perjanjian Lama (Jakarta: Gunung Mulia, 2004),76-77 
Milik pusaka dimiliki oleh seluruh keluarga, bukan oleh perseorangan, sebab itu ada hukum warisan yang mutlak. Putra sulung memperoleh dua kali lipat dan yang lain memperoleh bagian yang sama. Apabila suami meninggal dan tidak meninggalkan anak laki-laki, maka milik pusakanya berpindah pada anak perempuan, apabila tidak punya anak perempuan maka diberikan kepada saudara laki-lakinya, apabila tidak memiliki saudara laki-laki maka akan diberikan kepada saudara laki-laki ayahnya, dan apabila ayahnya tidak memiliki saudara laki-laki maka milik pusakanya diberikan kepada kerabat yang terdekat. ${ }^{25}$

- Warisan Sebagai Penerus Keturunan

Allah memberikan perintah dan ketetapan bagi Israel, yaitu milik pusaka mereka tidak boleh beralih dari suku ke suku, tetapi orang Israel haruslah masing-masing memegang milik pusaka suku nenek moyangnya (Bil 36:7,9). Dalam Perjanjian Lama, warisan tidak diperbolehkan untuk dialihkan kepada orang lain yang bukan keturunan keluarga tersebut. Sebab itulah yang menjadi ketetapan dan peraturan yang diberikan Allah untuk orang Israel. Karena itu pentingya seorang pewaris mewarisi warisan kepada ahli warisnya supaya warisan itu tidak jatuh kepada orang lain, melainkan kepada keturunannya supaya namanya tetap disebut dalam pusaka miliknya.

Sensus yang dicatat dalam pasal 26 , secara khusus di sebut kelima anak perempuan Zelafehad bin Hefer (26:33). Karena Zelafehad tidak memiliki anak laki-laki, sehingga anak-anak perempuan meminta kepada Musa supaya mereka dapat mewarisi tanah milik orang tuanya yang biasanya diwariskan kepada anak laki-laki. Setelah perkara itu diajukan maka Musa memberitahukan Tuhan apa yang hendak ia putuskan. Kemudian Musa memutuskan sesuai firman Allah bahwa apabila seorang laki-laki tidak mempunyai anak laki-laki maka anak perempuan berhak mewarisi warisan orang tuanya. Tetapi apabila seorang laki-laki tidak mempunyai anak laki-laki atau anak perempuan maka warisannya diberikan kepada saudara-saudara kandungnya laki-laki atau kepada saudara laki-laki ayahnya. Kemudian supaya warisan itu tetap di diwariskan oleh kaum keluarga ayahnya, maka Musa juga memberikan perintah sesuai firman Allah bahwa anak-anak perempuan yang mendapatkan hak waris dari ayahnya harus menikah dengan lelaki dari pihak saudara-saudara ayahnya. Ini menunjukkan bahwa betapa pentingnya warisan untuk dipertahankan tetap pada kaum keluarga Israel.

${ }^{25}$ J. D Douglas, Ensiklopedi Alkitab Masa Kini Jilid II, (Jakarta: Yayasan Komunikasi Bina Kasih, 1995), 84-85 
Contoh peristiwa yang terjadi demi mempertahankan warisan keluarga yaitu peristiwa penolakkan Nabot untuk menjual milik pusakanya kepada Raja Ahab di Yisreel (I Raj. 21:2-3).

Kesimpulan bahwa warisan keluarga sangat penting untuk dipertahankan, sebab warisan keluarga merupakan harta pusaka yang dimiliki atas nama keluarga sehingga sampai turun temurun warisan itu membawa nama keluarga. Warisan yang di wariskan oleh ahli waris memiliki tanggungjawab untuk mempertahankan dan mengembangkan atau mengerjakan sesuai apa yang dimiliki. Sehingga warisan ini sangat penting untuk dibagi supaya keturunan keluarga yang menjadi ahli waris dapat memiliki tempat atau sesuatu yang dapat dikembangkan.

Jadi warisan keluarga ini sangat penting untuk diberikan kepada ahli waris karena akan membawa nama keluarga, jika ahli waris menggunakan hak waris dengan tidak baik maka nama keluarga akan menjadi taruhannya. Sehingga umat larael dituntut Tuhan untuk mewarisi warisan harta pusaka yang telah di berikan oleh Allah kepada mereka supaya dapat menjaga nama baik sebagai umat pilihan Allah.

Jadi apabila di aplikasikan untuk saat ini bahwa warisan sangat penting dalam kehidupan seseorang sebab seorang ahli waris akan membawa nama keluarga dimanapun dia berada. Itu artinya warisan tidak hanya sekedar harta benda melainkan warisan hidup yang terlihat dalam perbuatan sehari-hari. Sesungguhnya warisan ini yang ditekankan oleh Allah kepada umat Israel supaya mereka dapat menjaga pola hidup mereka sebagai umat pilihan Allah. Sebab keteladan hidup adalah warisan yang paling berharga karena tidak dapat habis atau dapat hilang tetapi itu menjadi harta kekal yang di berikan kepada orang lain. Oleh sebab itu orang tua memiliki peran dan tanggungjawab dalam memberikan teladan hidup kepada anak-anaknya sebagai warisan kekal.

- Warisan Tidak Menjadi Sumber Masalah

Pembagian harta warisan tidak jarang merenggangkan hubungan antara saudara, bahkan membuat keluarga putus hubungan. Sebab itu sangat penting warisan harus segera dibagi supaya masing-masing memiliki hak atas apa yang menjadi bagiannya (Bil 27:8-11).

Pembagian warisan sangat penting dilakukan supaya setiap orang berhak memiliki warisan yang menjadi bagiannya. Banyak hal dapat diantisipasi untuk menjaga kerukunan dan keamanan baik di dalam keluarga maupun di dalam bermasyarakat. Warisan pada mulanya 
diberikan oleh Allah kepada bangsa Israel dalam bentuk tanah perjanjian Allah kepada umat-Nya. Namun dalam perkembangannya, warisan tidak hanya lagi dalam bentuk tanah namun berbagai macam.

Manusia memiliki harta yang berbagai macam bentuknya dan asal usulnya seperti warisan turun temurun dari nenek moyang, ada juga warisan yang diperoleh dari hasil pekerjaan seseorang sebelum ia berkeluarga, dan juga warisan yang diperoleh setelah berkeluarga. Namun pada hakekatnya, orang yang menjadi ahi waris memiliki tanggungjawab untuk menjaga dan menggunakan dengan sebaik-baiknya karena merupakan wasiat yang ditinggalkan oleh pewaris sebagai bentuk kasihnya, baik kepada anak-anaknya maupun kepada saudara-saudaranya.

\section{KESIMPULAN}

Persoalan pembagian warisan menjadi problem yang sangat serius dalam keluarga Kristen, sehingga pendalaman berkenaan dengan pembagian warisan dalam Bilangan 27: 1-11 menjadi pedoman untuk mengatasi dan mendasari persoalan dalam pembagian warisan. Tanggungjawab keharmonisan keluarga dipertanggungjawabkan kepada Tuhan, warisan janganlah menjadi perpecahan dalam keluarga namun menjadi penerus dan pemersatu keluarga sebagai pusaka keluarga.

Pemahaman arti penting warisan adalah membuat orang memahami bahwa warisan bukanlah bukan hanya sekedar harta benda yang dimiliki untuk kesenangan hidup atau sesuatu yang di peroleh untuk menjadi kebanggaan, tetapi warisan di berikan kepada ahli waris dengan tugas dan tanggungjawab yang besar yaitu untuk menjaga dan mengembangkan atau mengerjakan sesuai kapasitas yang di berikan oleh pewaris.

\section{DAFTAR PUSTAKA}

Asri, Benyamin dan Asri. 1988. Thabrani Dasar-dasar Hukum Waris Barat (suatu pembahasan Teoritis dan Praktek), Bandung: Tarsito.

Bible Work, 10 Februari 2019.

D.F. Walker. 1994. Konkordansi Alkitab. Jakarta: Gunung Mulia.

Departemen Pendidikan Nasional. 2008. Kamus Besar Bahasa Indonesia Pusat Bahasa Edisi Keempat, Jakarta: Gramedia Pustaka Utama.

Douglas, J. D. 1995. Ensiklopedi Alkitab Masa Kini Jilid II. Jakarta: Yayasan Komunikasi Bina Kasih.

Hadikusuma, Hilman. 1993. Hukum waris adat. Bandung: Citra aditya Bakti. 
Jebua. S .1984. Menelusuri Sejarah Kebudayaan Ono Niha.

Karman, Yonky. 2004. Bunga Rampai Teologi Perjanjian Lama. Jakarta: Gunung Mulia.

King, Philip J. dan Stager, Lawrence E. 2001. Kehidupan Orang Israel Alkitabiah, Jakarta: Gunung Mulia.

Lidahtinta.http// www.wordpress.com. Adat dan Hukum di Aceh, (Senin, 21/01/2019).

Mahadi. 1972. laporan hasil Penelitian Fakultas Hukum USU tentang Garisgaris Besar Hukum kekeluargaan dan Warisan di kalangan Suku Batak dan Nias, Lembaga Penelitian USU, Medan.

Novelaoli. Blogspot.com/2008. (Jumat, 19-10-2018), pukul 09.15 wib.

Schnittjer, Gary Edward, The Torah Story Malang: Gandum Mas, 2015.

Soekanto, Soerjono. 2001. Hukum Adat Indonesia. Jakarta: Raja Grafindo Persada.

Suparman. 2017. Maman Hukum Waris Perdata, Jakarta: Sinar Grafika. 
SIAP, Vol. 10 No.1, Juni 2021: 109-134 